

\title{
SERVICE QUALITY DIMENSIONS IN THE CONTEXT OF A CIVIL CONSTRUCTION TECHNOLOGY LABORATORY IN BRAZIL
}

\author{
DIMENSÕES DA QUALIDADE DOS SERVIÇOS NO CONTEXTO DE UM \\ LABORATÓRIO DE CONSTRUÇÃO CIVIL NO BRASIL
}

\section{Duélen Bebber ${ }^{1}$ \\ Marcelo Benetti Correa da Silva ${ }^{2}$ \\ Taila da Silveira ${ }^{3}$ \\ iD Gabriel Sperandio Milan ${ }^{4}$}

${ }^{1}$ Mestre em Administração Universidade de Caxias do Sul - UCS. Caxias do Sul, Rio Grande do Sul - Brasil. bebber.suelen@gmail.com

${ }^{2}$ Mestre em Administração Universidade de Caxias do Sul - UCS. Caxias do Sul, Rio Grande do Sul - Brasil. mbsilva@ucs.br

${ }^{3}$ Graduada em Engenharia Civil Universidade de Caxias do Sul - UCS. Caxias do Sul, Rio Grande do Sul - Brasil. tsilveira@ucs.br

${ }^{4}$ Doutor em Engenharia de Produção Universidade do Vale do Rio dos Sinos - UNISINOS. São Leopoldo, Rio Grande do Sul - Brasil. gsmilan@unisinos.br

Recebido em: 26 ago. 2019

Aprovado em: 13 fev. 2020
Abstract: This research aimed to compare the service quality dimensions of a civil construction material technology laboratory from concrete specimen and ceramic brick-breaking services customers. Multiple regression analyses were performed from the most important quality dimensions resulting from customers' perception, obtained from four previous studies that applied factor analyses. The values obtained in the factor and regression analyses were correlated to identify similar results found in the analyses. The results pointed that the attributes related to the personalized attendance, information about the assay results, and staff commitment, are considered the most important ones from customers' perception. As a result, fragilities in the performed service could be identified, and improvements proposed, maximizing customer satisfaction. As a study limitation, the small sample size is pointed, which could have influenced the results and the methodology procedures in the regression analyses.

Keywords: Service quality dimensions. Service quality. Customer satisfaction. Technological laboratory.

Resumo: O objetivo desta pesquisa foi o de comparar as dimensões da qualidade do serviço de um laboratório de tecnologia de materiais de construção civil a partir da perspectiva dos clientes de serviços de corpo de prova de concreto e rompimento de tijolos cerâmicos. Foram realizadas múltiplas análises de regressão a partir dos resultados das dimensões de qualidade mais importantes resultantes da percepção dos clientes, obtidas a partir de quatro estudos anteriores, que aplicaram análise fatorial. Os valores obtidos nas análises fatoriais e de regressão foram correlacionados com o objetivo de identificar resultados semelhantes nas análises. Os resultados apontam que os atributos relacionados com o atendimento personalizado, informação sobre os resultados do ensaio, bem como o comprometimento dos funcionários, são considerados os mais importantes na percepção dos clientes. Assim, foi possível identificar fragilidades no serviço realizado e propor melhorias e, desta forma, maximizar a satisfação do cliente. Como limitação do estudo, é apontado o tamanho da amostra, que poderia ter influenciado os resultados encontrados, influenciando também os procedimentos metodológicos nas análises de regressão.

Palavras-chave: Dimensões da qualidade do serviço. Qualidade do serviço. Satisfação do cliente. Laboratório tecnológico. 
1 Introduction

Recent studies have revealed an accelerated growth in the service sector in developed countries. It represents over $50 \%$ of the gross domestic product, as is the United States example, where this activity represents 80\% of the GDP (Grönroos, 2007; Valenzuela, Estocalenko, Rojas and Raymundo, 2019). In Brazil, data from IBGE (Brazilian Institute of Geography and Statistics) (2017) revealed a representative growth of the service sector in the country's economy. For a long time, services were considered a complement for products but did not generate a significant amount for companies and society. Nowadays, service importance is still neglected in some situations, mainly when it is considered an economic sphere and not seen as the chance for obtaining a competitive advantage (Grönroos, 2007)

Services are present in our day-to-day life, even though they are not realized: when we fill the car's tank, we send a letter or in a doctor's appointment. Data obtained in the Service Annual Research (IBGE, 2017) showed that the sector is also growing: in 2017, 1,286,621 service companies were identified, which generated $\mathrm{R} \$ 1.4$ trillion of liquid operational income, and employed more than 12 million people.

The sector's growth has not gone unnoticed by researchers. Competitiveness is growing, customers' demands are increasing, and service providers need to deliver competitive differentials to keep in the market. Service encounters represent the foundation for business success since positive service encounters influence customers' satisfaction and repurchase intention (Kaatz, 2020). For this reason, the investment in quality and customer satisfaction is essential. Customer satisfaction is generally defined as a feeling or judgment of customers toward products or services after they have used or experienced them (Quan, 2010; Gupta and Bansal, 2012). Whereas service quality is an overall assessment of the services, satisfaction derives from the overall evaluation of the experience with those services (George and Kumar, 2014).

A variety of service sectors has recently studied service quality, as an example of Marimon, Llach, Almeida and Machuca (2019), who validated a scale to assess the quality of services provided through a collaborative consumption model. Moreover, Punel, Hassan and Ermagun (2019), explored the interdependence between passenger travel experience and service quality in the airline industry.

This research's case study is LABTEC, a technology laboratory, one of the 670 laboratories of the University of Caxias do Sul, located in southern Brazil. Its operation started in 2002, initially to attend architecture students, and, in 2004, it began offering assay services to the general community. The laboratory performs different types of essays, like brick and blocks resistance, concrete specimen, cement, and buildings in loco performance. Nowadays, it counts on 73 active customers, and $74.5 \%$ of them hire concrete specimen-breaking services to identify if the concrete resistance is according to the 
specified in the project. Other $5 \%$ of the customers hire ceramic brick-breaking services, aiming to evaluate the brick resistance, mainly when structural masonry structures are used.

Based on previous studies, the main contribution regarding the present study was to adapt the most assertive way that managers could proceed with a quality evaluation concerning their attributes or dimensions, considering the analyzed context (civil construction technology laboratory) and its particularities. The question guiding this research was: What service quality dimensions are more important for service users? Therefore, the present research aimed to compare the quality dimensions of the services delivered by the laboratory according to the importance perceived by customers of concrete specimen breaking and ceramic brick-breaking services. Regression analyses were performed, with the results obtained in factor analyses from four previous studies performed in the laboratory.

In order to meet the proposed objectives, the theoretical framework concerning service quality, customer satisfaction, and the dimensions of service quality is presented. Next, the research method is presented, the results analyses, and the final considerations.

\section{Theoretical framework}

Services are defined, in simple words, as actions, processes, and performance (Alan et al., 2012). They cannot be touched like a product. Therefore, the negotiation approach must differ too. Services are simultaneous, as they are produced and consumed at the same time (Jhone and Storey, 1998). The level of quality in which a company delivers its service to customers is a central question that deserves attention (Gounaris, 2005). It is considered a determinant factor of business performance and the viability of companies in a long-term perspective. Therefore, it has been used as a strategic alternative to consolidate and increase companies' performance (Grönroos, 2007).

The understanding that each customer has a particular need and that the relationship is a differential for companies is crucial to building relations that aim at customers' retention and loyalty. Some customers value a long-term relationship and mutual benefits for both parties, while others are only interested in relational exchanges (Gummensson, 1996; Gordon, 2001). It is the company's job to understand and distinguish such customers to devote the needed efforts where there are real chances of a long-term relationship.

Service quality was defined as customers' overall assessment of service (Ganguli and Roy, 2011) or comparing customers' perception of the service experienced and their expectations before the service were delivered (Fitzsimmons, Fitzsimmons and Bordoloi, 2008). If the expectations are exceeded, the service is considered exceptional, which is a pleasant surprise. When the expectations were not met, the service is unacceptable, and the customer received something inferior to expected. The quality is satisfactory if the service was performed as expected (Fitzsimmons, Fitzsimmons and Bordoloi, 2008). That is why there is convergence in the understanding that perceived quality is an 
antecedent or a determinant factor of customer satisfaction (Gremler and Gwinner, 2000; Lee, Lee and Yoo, 2000; Cheng, Proverbs and Oduoza, 2006; Junnonen, Sorlvala and Kärnä, 2009; Oliver, 2010; Oh and Kim, 2017).

Oliver (2010) conceptualized satisfaction as a plenitude answer from the customer or consumer. A judgment that a product and/or service has the characteristic of having provided, or to be providing, a pleasant level of plenitude related to the process of purchase and/or consumption, which can include lower levels of expectation (negative disconfirmation) or that surpasses the expected level (positive disconfirmation). Satisfaction is the degree to which the customers' expectations have been supplied, or not, by the received benefits (Juran and De Feo, 2010; Forsythe, 2012).

Measuring service quality is a challenge because customer delight happens due to intangible and untouchable factors (Fitzsimmons, Fitzsimmons and Bordoloi, 2008). A great part of the studies evaluate quality through disconfirmation: quality is measured by comparing expectations and experiences (Grönroos, 2007). Accordingly, to measure quality, it is possible to evaluate attributes that are grouped in quality dimensions. Fitzsimmons, Fitzsimmons and Bordoloi (2008) grouped the attributes in five dimensions: the first that customers judge when evaluating perceived service quality: reliability, responsiveness, assurance, empathy, and tangibles.

One scale used to measure quality dimensions is the SERVQUAL scale (Parasuraman, Zeithaml and Berry, 1988). The objective of the scale is to measure the quality of the services performed and improve the services, from the identification of the customer need, evaluating the five quality dimensions previously mentioned. Milan et al. (2014) explained that this model is based on the difference between the customer's expectation when hiring a service and the perception when the service is delivered. Such differences are measured as quality gaps, where imperfections between the expected and the provided services are pointed. The use of the scale equally in every service has been questioned. Consequently, it is important to attribute different magnitudes to each dimension according to the service performed (Milan et al., 2014; Liu and Tse, 2018).

\section{Research method}

We used quantitative data from previous research to customers of concrete specimen-breaking services and ceramic brick-breaking services to develop the present research. The Exploratory Factor Analyses was applied in those researches (Johnson and Wickern, 2007; Mulaik, 2010; Malhotra, Birk and Wilss, 2012; Gorsuch, 2015). In total, four quantitative studies were performed previously: two of them using a SERVQUAL adapted scale (Parasuraman, Zeithaml and Berry, 1988), and the remaining two, based on Lazzari (2009) adapted scale. The results of factor analyses performed in previous studies 
named Studies A, B, C, and D were considered to perform multiple regression analyses in the present research.

A quantitative methodological approach was applied through a survey for the research operationalization of the four mentioned studies (Fowler Jr., 2009; Fink, 2012). Concerning the data collection method, first, the respondents were contacted by telephone to learn about the research, and an interview appointment was scheduled. On the scheduled day and time, the researcher called the respondent that received an e-mail link to answer the research. While the respondent marked the answers on the computer, the researcher helped to answer the questionnaire.

\subsection{Participants (Sample)}

At the time of the research, the LBTEC counted on 105 concrete specimen-breaking customers, of which 39 answered the research in Study A and C, simultaneously applying the different scales. Customers of ceramic brick-breaking were 42 , and 30 answered the researches of Studies B and D, as shown in Table 5. Nowadays, LBTEC counts with 73 active customers. Up to June 2018, 3.475 assays have already been performed by the laboratory; $74.5 \%$ of those are represented by concrete specimenbreaking and 5\% ceramic brick-breaking. Table 1 presents the primary data of the study participants.

Table 1

Studies $A, B, C$, and D Respondents

\begin{tabular}{ccccccc}
\hline Studies & Populations & Samples & Sample $\%$ & Valid Cases & Valid \% & $\begin{array}{c}\text { Total } \\
\text { Sample \% }\end{array}$ \\
\hline A & 105 & 39 & 37.14 & 39 & 37.14 & 37.14 \\
B & 42 & 30 & 71.43 & 30 & 71.43 & 71.43 \\
C & 105 & 39 & 37.14 & 39 & 37.14 & 37.14 \\
D & 42 & 30 & 71.43 & 30 & 71.43 & 71.43 \\
\hline
\end{tabular}

Source: The authors.

\subsection{Data (Factor Analyses)}

For a better understanding, the research performed with concrete specimen-breaking customers using the adapted SERVQUAL scale will be called Study A (Da Silva et al., 2017). The research performed with ceramic brick-breaking customers using the adapted SERVQUAL scale will be called Study B (Da Silva et al., 2018). The research performed with concrete specimen breaking customers using the customized Lazzari scale will be called Study C. Finally, the research performed with ceramic brick-breaking customers using the customized Lazzari scale will be called Study D. Table 2 presents the attributes retained in the factor analyses of Study A and Table 3 of Study C. The studies resulted in different dimensions, although the same scale was applied. 
Table 2

Adapted SERVQUAL Scale Attributes: Study A

\begin{tabular}{|c|c|c|c|c|c|c|}
\hline Dimensions & Attributes & $\begin{array}{l}\text { Factor } \\
\text { Loadings } \\
\end{array}$ & $\begin{array}{c}\text { Commu- } \\
\text { nalities }\end{array}$ & Gaps & $\begin{array}{c}\text { Gaps by } \\
\text { Dimensions }\end{array}$ & $\begin{array}{c}\text { Cronbach's } \\
\text { Alpha }\end{array}$ \\
\hline \multirow{5}{*}{ Tangible } & $\begin{array}{l}\text { Up-to-date } \\
\text { equipment }\end{array}$ & 0.770 & 0.829 & -0.839 & \multirow{5}{*}{-0.875} & \multirow{5}{*}{0.834} \\
\hline & $\begin{array}{l}\text { Visually appealing } \\
\text { physical facilities }\end{array}$ & 0.789 & 0.817 & -1.038 & & \\
\hline & $\begin{array}{lr}\text { Well dressed and } \\
\text { good appearance } \\
\text { staff }\end{array}$ & 0.849 & 0.784 & 0.288 & & \\
\hline & $\begin{array}{l}\text { Staff whose behavior } \\
\text { instills confidence in } \\
\text { the customer }\end{array}$ & 0.570 & 0.530 & -1.480 & & \\
\hline & $\begin{array}{l}\text { The staff gets } \\
\text { support, training and } \\
\text { proper orientation to } \\
\text { perform well the job }\end{array}$ & 0.637 & 0.761 & -1.307 & & \\
\hline \multirow{7}{*}{ Reliability } & $\begin{array}{l}\text { Provide results in a } \\
\text { clear and easy way }\end{array}$ & 0.729 & 0.888 & -3.414 & \multirow{7}{*}{-1.418} & \multirow{7}{*}{0.917} \\
\hline & $\begin{array}{l}\text { Helpful staff when the } \\
\text { customers have a } \\
\text { problem }\end{array}$ & 0.799 & 0.924 & -1.659 & & \\
\hline & Be trustful & 0.893 & 0.797 & -0.523 & & \\
\hline & $\begin{array}{l}\text { Provide the service up } \\
\text { to the promised } \\
\text { deadline }\end{array}$ & 0.603 & 0.780 & -0.523 & & \\
\hline & $\begin{array}{l}\text { Keep correct and up- } \\
\text { to-date registers }\end{array}$ & 0.926 & 0.887 & -0.315 & & \\
\hline & $\begin{array}{l}\text { Communicate the } \\
\text { customer when the } \\
\text { service is performed }\end{array}$ & 0.781 & 0.729 & -1.787 & & \\
\hline & $\begin{array}{l}\text { Staff who are polite } \\
\text { with customers }\end{array}$ & 0.760 & 0.871 & -0.843 & & \\
\hline \multirow{3}{*}{ Assurance } & $\begin{array}{l}\text { Staff who have the } \\
\text { knowledge to provide } \\
\text { immediate answers to } \\
\text { customers questions }\end{array}$ & -0.850 & 0.885 & -0.013 & \multirow{3}{*}{-0.947} & \multirow{3}{*}{0.819} \\
\hline & $\begin{array}{l}\text { Staff willing to help } \\
\text { the customers }\end{array}$ & -0.530 & 0.763 & -0.227 & & \\
\hline & $\begin{array}{l}\text { The staff makes } \\
\text { customers feel safe in } \\
\text { negotiations }\end{array}$ & -0.820 & 0.844 & -0.044 & & \\
\hline \multirow{3}{*}{ Responsiveness } & $\begin{array}{l}\text { Offer individualized } \\
\text { care to customers }\end{array}$ & 0.867 & 0.816 & -1.007 & \multirow{3}{*}{-0.095} & \multirow{3}{*}{0.824} \\
\hline & $\begin{array}{lr}\text { Staff who give } \\
\text { personalized } \\
\text { attention } \\
\text { customers }\end{array}$ & 0.779 & 0.827 & -0.800 & & \\
\hline & $\begin{array}{l}\text { Flexible business } \\
\text { hours }\end{array}$ & 0.809 & 0.769 & -1.034 & & \\
\hline Empathy & $\begin{array}{l}\text { Staff who know how } \\
\text { to identify the } \\
\text { customers' needs }\end{array}$ & 0.630 & 0.833 & -1.605 & -1.496 & 0.765 \\
\hline
\end{tabular}




\begin{tabular}{c|c|c|c|c|c|c}
\hline Dimensions & Attributes & $\begin{array}{c}\text { Factor } \\
\text { Loadings }\end{array}$ & $\begin{array}{c}\text { Commu- } \\
\text { nalities }\end{array}$ & Gaps & $\begin{array}{c}\text { Gaps by } \\
\text { Dimensions }\end{array}$ & $\begin{array}{c}\text { Cronbach's } \\
\text { Alpha }\end{array}$ \\
\hline Empathy & $\begin{array}{c}\text { Have the customers' } \\
\text { best interests at heart }\end{array}$ & 0.810 & 0.750 & -1.387 & & \\
\hline
\end{tabular}

Source: Data adapted from Study A (Da Silva et al., 2017).

Note: \%Explained Variance: 80.417; KMO: 0.610. Bartlett Test of Sphericity: Q Square: 726.5226. DF: 190.000; sig.: 0.000 .

In study $A$, the dimension that showed a higher gap was Empathy (-1.496), followed by Reliability (-1.418). Regarding the attributes, "Provide results in a clear and easy way" showed the highest gap (-3.414) followed by "Helpful staff when the customers have a problem" (-1.659), both from the Reliability dimension. Only the attribute "Well dressed and good appearance staff" presented a positive gap. All Cronbach's Alpha values were satisfactory (Malhotra, Birks and Wills, 2012), ranging from 0.765 to 0.917 .

Table 3

Adapted SERVQUAL Scale Attributes: Study B

\begin{tabular}{|c|c|c|c|c|c|c|}
\hline Dimensions & Attributes & $\begin{array}{l}\text { Factor } \\
\text { Loadings }\end{array}$ & $\begin{array}{l}\text { Commu- } \\
\text { nalities }\end{array}$ & Gaps & $\begin{array}{c}\text { Gaps by } \\
\text { Dimensions }\end{array}$ & $\begin{array}{c}\text { Cronbach's } \\
\text { Alpha }\end{array}$ \\
\hline \multirow{4}{*}{ Reliability } & $\begin{array}{l}\text { Up-to-date } \\
\text { equipment }\end{array}$ & -0.908 & 0.731 & -0.333 & \multirow{4}{*}{-0.706} & \multirow{4}{*}{0.866} \\
\hline & $\begin{array}{l}\text { Facilities adequate for } \\
\text { the type of service }\end{array}$ & -0.569 & 0.747 & -0.955 & & \\
\hline & $\begin{array}{l}\text { Helpful staff when the } \\
\text { customers have a } \\
\text { problem }\end{array}$ & -0.518 & 0.717 & -0.931 & & \\
\hline & $\begin{array}{l}\text { Keep correct and up- } \\
\text { to-date registers }\end{array}$ & -0.603 & 0.766 & -0.606 & & \\
\hline \multirow{7}{*}{ Responsiveness } & $\begin{array}{l}\text { Visually appealing } \\
\text { physical facilities }\end{array}$ & 0.582 & 0.727 & -0.785 & \multirow{7}{*}{-0.815} & \multirow{7}{*}{0.971} \\
\hline & $\begin{array}{lr}\text { Well } & \text { dressed and } \\
\text { good } & \text { appearance } \\
\text { staff } & \end{array}$ & 0.779 & 0.541 & -0.782 & & \\
\hline & $\begin{array}{l}\text { Provide results in a } \\
\text { clear and easy way }\end{array}$ & 0.870 & 0.717 & -0.847 & & \\
\hline & $\begin{array}{l}\text { Provide the service up } \\
\text { to the promised } \\
\text { deadline }\end{array}$ & 0.628 & 0.772 & -0.609 & & \\
\hline & $\begin{array}{l}\text { Communicate the } \\
\text { customers when the } \\
\text { service is performed }\end{array}$ & 0.812 & 0.766 & -0.210 & & \\
\hline & $\begin{array}{l}\text { Staff who have the } \\
\text { knowledge to provide } \\
\text { immediate answers to } \\
\text { customers questions }\end{array}$ & 0.846 & 0.758 & -0.586 & & \\
\hline & $\begin{array}{l}\text { Staff willing to help } \\
\text { the customers }\end{array}$ & 0.711 & 0.683 & -0.759 & & \\
\hline
\end{tabular}




\begin{tabular}{|c|c|c|c|c|c|c|}
\hline Dimensions & Attributes & $\begin{array}{l}\text { Factor } \\
\text { Loadings }\end{array}$ & $\begin{array}{l}\text { Commu- } \\
\text { nalities }\end{array}$ & Gaps & $\begin{array}{c}\text { Gaps by } \\
\text { Dimensions }\end{array}$ & $\begin{array}{c}\text { Cronbach's } \\
\text { Alpha }\end{array}$ \\
\hline \multirow{8}{*}{ Responsiveness } & $\begin{array}{l}\text { Staff whose behavior } \\
\text { instills confidence in } \\
\text { the customer }\end{array}$ & 0.900 & 0.757 & -0.780 & & \\
\hline & $\begin{array}{l}\text { The staff makes } \\
\text { customers feel safe in } \\
\text { negotiations }\end{array}$ & 0.614 & 0.877 & -1.123 & & \\
\hline & $\begin{array}{l}\text { Staff who are polite } \\
\text { with customers }\end{array}$ & 0.932 & 0.836 & -1.047 & & \\
\hline & $\begin{array}{l}\text { The staff gets } \\
\text { support, training and } \\
\text { proper orientation to } \\
\text { perform well the job }\end{array}$ & 0.888 & 0.839 & -0.918 & & \\
\hline & $\begin{array}{l}\text { Offer individualized } \\
\text { care to customers }\end{array}$ & 0.645 & 0.850 & -1.095 & & \\
\hline & 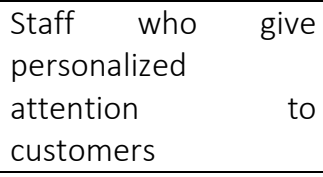 & 0.698 & 0.818 & -1.033 & & \\
\hline & $\begin{array}{l}\text { Have the customer's } \\
\text { best interests at heart }\end{array}$ & 0.812 & 0.765 & -0.756 & & \\
\hline & $\begin{array}{l}\text { Flexible business } \\
\text { hours }\end{array}$ & 0.998 & 0.794 & -0.894 & & \\
\hline Assurance & $\begin{array}{l}\text { Staff who know how } \\
\text { to identify the } \\
\text { customer' needs }\end{array}$ & 0.940 & 0.887 & -0.905 & 0 & 0 \\
\hline
\end{tabular}

Source: Data adapted from Study B (Da Silva et al., 2018).

Note: \% Explained Variance: 77.621 Note: KMO: 0.610. Bartlett Test of Sphericity: Q Square: 663.875. DF: 190.000; sig.: 0.000 .

Concerning study $B$, the analyses resulted in just three dimensions, and one of them just one attribute. Responsiveness presented the higher gap (-0.815) followed by Reliability (0.706). The attributes, "The staff makes customers feel safe in negotiations," showed the highest gap (-1.123) followed by "Offer individualized care to customers" (-1.095), both from the Responsiveness dimension. In general, all attributes presented negative gap values. The Cronbach's Alpha values were satisfactory, 0.866 for Reliability, and 0.971 for Responsiveness. The dimension Assurance was kept in the analyses due to the high factor loading presented by the attribute "Staff who know how to identify the customer' needs."

Studies C and D, where the customized Lazzari (2009) scale was applied, the attributes were also grouped differently after the factor analyses. Table 4 presents the results obtained in Study C concerning concrete specimen-breaking services. The results obtained in study D, performed with customers of ceramic brick-breaking services, are presented in Table 5. 
Table 4

Lazzari Customized Scale Attributes: Study C

\begin{tabular}{|c|c|c|c|c|}
\hline Dimensions & Attributes & $\begin{array}{c}\text { Factor } \\
\text { Loadings } \\
\end{array}$ & $\begin{array}{c}\text { Commu- } \\
\text { nalities }\end{array}$ & $\begin{array}{c}\text { Cronbach's } \\
\text { Alpha }\end{array}$ \\
\hline \multirow{3}{*}{ Agility } & Agility in the e-mail attendance & 0.815 & 0.855 & \multirow{3}{*}{0.817} \\
\hline & Agility in the telephone attendance & 0.738 & 0.862 & \\
\hline & Price of assays and tests & 0.584 & 0.723 & \\
\hline \multirow{4}{*}{ Infrastructure } & $\begin{array}{l}\text { The clarity in the discrimination of the assays in } \\
\text { the invoice }\end{array}$ & 0.544 & 0.727 & \multirow{4}{*}{0.807} \\
\hline & Equipment maintenance and control & 0.796 & 0.800 & \\
\hline & Parking & 0.832 & 0.815 & \\
\hline & Technical team qualification & 0.819 & 0.878 & \\
\hline \multirow{3}{*}{ Credibility } & $\begin{array}{l}\text { The commitment of the technical team with } \\
\text { the customer }\end{array}$ & 0.874 & 0.916 & \multirow{3}{*}{0.895} \\
\hline & The credibility of the institution brand & 0.775 & 0.878 & \\
\hline & The credibility of the technological lab & 0.687 & 0.906 & \\
\hline \multirow{5}{*}{ Reliability } & Doubts clarification by telephone attendance & 0.855 & 0.924 & \multirow{5}{*}{0.884} \\
\hline & Ethics in procedures & 0.613 & 0.855 & \\
\hline & $\begin{array}{l}\text { Explanations on the assays performing with a } \\
\text { scientific basis }\end{array}$ & 0.809 & 0.842 & \\
\hline & $\begin{array}{l}\text { Previous information providing concerning the } \\
\text { results of the assays }\end{array}$ & 0.833 & 0.904 & \\
\hline & $\begin{array}{l}\text { A satisfactory answer to the complaints } \\
\text { performed to the lab, when it is the case }\end{array}$ & 0.747 & 0.759 & \\
\hline \multirow{3}{*}{$\begin{array}{l}\text { Assurance in } \\
\text { Service Execution }\end{array}$} & Lab business hours & 0.538 & 0.752 & \multirow{3}{*}{0.781} \\
\hline & $\begin{array}{l}\text { Technical solutions proposed by the lab team } \\
\text { when solicited }\end{array}$ & 0.791 & 0.906 & \\
\hline & Answer time to deliver the contract & 0.865 & 0.870 & \\
\hline \multirow{4}{*}{$\begin{array}{l}\text { Assurance in } \\
\text { Service Delivery }\end{array}$} & Lab's location & 0.822 & 0.828 & \multirow{4}{*}{0.918} \\
\hline & $\begin{array}{l}\text { Orientations in relation to the concrete } \\
\text { specimen }\end{array}$ & 0.840 & 0.863 & \\
\hline & Results delivery punctuality & 0.894 & 0.886 & \\
\hline & Results deadline & 0.839 & 0.917 & \\
\hline \multirow[b]{2}{*}{ Responsiveness } & Results confidentiality & 0.756 & 0.873 & \multirow[b]{2}{*}{0.792} \\
\hline & $\begin{array}{l}\text { Final report presentation (structure, } \\
\text { aesthetics, information deepness...) }\end{array}$ & 0.903 & 0.952 & \\
\hline
\end{tabular}

Source: Data adapted from Study C.

Note: \% Explained Variance: 85.379 Note: KMO: 0.577. Bartlett Test of Sphericity: Q Square: 959.189. DF: 190.000; sig.: 0.000 .

Study C resulted in the dimensions Agility, Infrastructure, Credibility, Reliability, Assurance in service delivery, and Responsiveness. In total, 24 attributes resulted from the factor analyses. The Cronbach's Alpha of all dimensions was satisfactory, ranging from 0.781 to 0.918 . 
Table 5

Lazzari Customized Scale Attributes: Study D

\begin{tabular}{|c|c|c|c|c|}
\hline Dimensions & Attributes & $\begin{array}{c}\text { Factor } \\
\text { Loadings } \\
\end{array}$ & $\begin{array}{l}\text { Commu- } \\
\text { nalities }\end{array}$ & $\begin{array}{c}\text { Cronbach's } \\
\text { Alpha }\end{array}$ \\
\hline \multirow{5}{*}{$\begin{array}{l}\text { Attention / } \\
\text { Assistance }\end{array}$} & Results delivery punctuality & 0.945 & 0.850 & \multirow{5}{*}{0.898} \\
\hline & $\begin{array}{l}\text { Final report presentation (structure, aesthetics, } \\
\text { information deepness...) }\end{array}$ & 0.883 & 0.881 & \\
\hline & The credibility of the technological lab & 0.735 & 0.819 & \\
\hline & $\begin{array}{l}\text { Explanations on the assays performing with a } \\
\text { scientific basis }\end{array}$ & 0.613 & 0.751 & \\
\hline & $\begin{array}{l}\text { Previous information providing concerning the } \\
\text { results of the assays }\end{array}$ & 0.505 & 0.792 & \\
\hline \multirow{3}{*}{ Cordiality } & Doubts clarification by telephone attendance & 0.919 & 0.847 & \multirow{3}{*}{0.716} \\
\hline & Attendance cordiality & 0.671 & 0.708 & \\
\hline & $\begin{array}{l}\text { Attendance of the specific needs of the } \\
\text { company }\end{array}$ & 0.580 & 0.687 & \\
\hline \multirow{4}{*}{ Competence } & Answer time to deliver the contract & -0.843 & 0.812 & \multirow{4}{*}{0.863} \\
\hline & $\begin{array}{l}\text { Sample collection service (care in the routing, } \\
\text { handling and characteristics preservation) }\end{array}$ & -0.751 & 0.809 & \\
\hline & $\begin{array}{l}\text { Assay performing according to established } \\
\text { norms }\end{array}$ & -0.729 & 0.747 & \\
\hline & Technical team qualification & -0.648 & 0.714 & \\
\hline \multirow{3}{*}{$\begin{array}{l}\text { Credibility / } \\
\text { Integrity }\end{array}$} & The credibility of the institution brand & 0.898 & 0.836 & \multirow{3}{*}{0.808} \\
\hline & Results confidentiality & 0.704 & 0.889 & \\
\hline & Results reliability & 0.530 & 0.832 & \\
\hline \multirow{2}{*}{ Access } & Lab business hours & 0.908 & 0.868 & \multirow{2}{*}{0.780} \\
\hline & Price of assays and tests & 0.796 & 0.880 & \\
\hline \multirow{3}{*}{ Tangible } & Lab's location & -0.924 & 0.849 & \multirow{3}{*}{0.821} \\
\hline & $\begin{array}{l}\text { The clarity in the discrimination of the assays in } \\
\text { the invoice }\end{array}$ & -0.707 & 0.901 & \\
\hline & Parking & -0.634 & 0.830 & \\
\hline
\end{tabular}

Source: Data adapted from Study D.

Note: \% Explained Variance: 81.508 Note: KMO: 0.629. Bartlett Test of Sphericity: Q Square: 472.572. DF: 190.000; sig.: 0.000 .

In relation to Study $\mathrm{D}$, the resultant dimensions were Attention/assistance, Cordiality, Competence, Credibility/integrity, Access, and Tangible, in a total of 20 attributes. The Cronbach's Alpha of all dimensions was satisfactory, ranging from 0.716 to 0.898 .

The main results obtained in the factor analyses are presented in Figure 1, and the dimensions retained in each of the four studies in importance order (with higher Cronbach's Alpha) and amount of attributes grouped. By analyzing the figure, it is possible to realize that the most important dimensions in the view of the customers repeat: attention, cordiality, customer attendance, and service delivery are very important factors in the customers' quality perception, both for the concrete specimen breaking and ceramic brick-breaking services. 


\section{Figure 1}

Conclusions on the Factor Analyses

\begin{tabular}{|c|c|c|c|c|}
\hline Studies & Service & Scales & Dimensions and Attributes Number & Main Research Findings \\
\hline A & $\begin{array}{l}\text { Concrete } \\
\text { specimen } \\
\text { breaking }\end{array}$ & $\begin{array}{c}\text { Adapted } \\
\text { SERVQUAL }\end{array}$ & $\begin{array}{l}\text { Reliability (7) } \\
\text { Tangibles (5) } \\
\text { Responsiveness (3) } \\
\text { Assurance (3) } \\
\text { Empathy (2) }\end{array}$ & $\begin{array}{l}\text { Negative gaps between } \\
\text { expectations (greater) and } \\
\text { perceptions. Higher gaps: empathy } \\
\text { and reliability }\end{array}$ \\
\hline B & $\begin{array}{l}\text { Ceramic } \\
\text { brick } \\
\text { breaking }\end{array}$ & $\begin{array}{l}\text { Adapted } \\
\text { SERVQUAL }\end{array}$ & $\begin{array}{l}\text { Responsiveness (15) } \\
\text { Reliability (4) } \\
\text { Assurance (1) }\end{array}$ & $\begin{array}{l}\text { Limitations: just one attribute } \\
\text { explains the dimension assurance } \\
\text { and the study resulted in just three } \\
\text { dimensions }\end{array}$ \\
\hline C & $\begin{array}{l}\text { Concrete } \\
\text { specimen } \\
\text { breaking }\end{array}$ & $\begin{array}{l}\text { Customized } \\
\text { Lazzari scale }\end{array}$ & $\begin{array}{c}\text { Assurance in service delivery (4) } \\
\text { Credibility (3) } \\
\text { Reliability (5) } \\
\text { Agility (3) } \\
\text { Infrastructure (4) } \\
\text { Responsiveness (2) } \\
\text { Assurance in service execution (3) }\end{array}$ & $\begin{array}{l}\text { Assurance in service delivery, } \\
\text { credibility, and reliability were the } \\
\text { dimensions that better explained } \\
\text { service quality }\end{array}$ \\
\hline D & $\begin{array}{l}\text { Ceramic } \\
\text { brick } \\
\text { breaking }\end{array}$ & $\begin{array}{l}\text { Customized } \\
\text { Lazzari scale }\end{array}$ & $\begin{array}{c}\text { Attention/Assistance (5) } \\
\text { Competence (4) } \\
\text { Tangible (3) } \\
\text { Credibility/Integrity (3) } \\
\text { Access (2) } \\
\text { Cordiality (3) }\end{array}$ & $\begin{array}{l}\text { Attention/Assistance and } \\
\text { competence were the dimensions } \\
\text { that better explained service quality }\end{array}$ \\
\hline
\end{tabular}

Source: The authors.

Regression analyses were performed with the results of the studies mentioned above individually. Regression analysis is a statistical model used to relate a dependent variable to another independent one (Malhotra, Birks and Wills, 2012; Tabachnick and Fidell, 2012). This kind of analysis is used to identify if this dependency relation is confirmed and the intensity of this connection, besides discovering a mathematics equation for such correlation (Malhotra, Birks and Wills, 2012; Meyers, Gamst and Guarino, 2013). Freund (2004) defined regression as the capability of reviewing the mean value of a variable through the relation with other variables of known values.

For the regression analysis, the dependent variable considered was "Customer Satisfaction." The sample size was too small for regression analysis (Hair Jr. et al., 2010; Meyers, Gamst and Guarino, 2013); because of that, the independent variables considered were the quality dimensions retained in each study. The sample size has an important impact on the statistical significance, both for the too big samples and the too small ones (Hair Jr. et al., 2010; Malhotra, Birks and Wills, 2012).

It is common to adopt a rule that there must be at least five observations for each dependent variable, a 5 to 1 ratio. However, the ideal is that this ratio is 15 or 20 to 1 (Hair Jr. et al., 2010; Malhotra, Birks and Wills, 2012). This would not be possible due to the sample and the population size. For so, the means of the attributes grouped in each dimension were calculated, and so, the independent variables 
considered were the quality dimensions retained in the factor analyses. After calculating the means, the regression analyses were performed individually for each study, with 95\% reliability.

\section{Research results}

\subsection{Salient service quality dimensions}

Table 6 presents the beta coefficient, coefficient of determination $R^{2}$, and adjusted $R^{2}$ for the dimensions that presented more meaningful results after the regression analyses. According to the respondents, the beta coefficient indicates which quality dimensions are the most important (Malhotra, Birks and Wills, 2012). The $\mathrm{R}^{2}$ determinant coefficient is related to the dependent variable variation concerning the mean (Hair Jr. et al., 2010; Tabachnick and Fidell, 2012). The authors stressed that this coefficient might vary between 0 and 1 , where greater values of $R^{2}$ tend to justify the regression equation. The adjusted $R^{2}$ is a modification of the $R$ determinant coefficient and is calculated considering the independent variables and the sample size.

Table 6

Most Important Service Quality Dimensions

\begin{tabular}{|c|c|c|c|c|}
\hline Studies & Most Important Service Quality Dimensions & Beta & $\mathrm{R}^{2}$ & $\begin{array}{c}R^{2} \\
\text { Adjusted }\end{array}$ \\
\hline A & $\begin{array}{l}\text { Reliability } \\
\text { Assurance }\end{array}$ & $\begin{array}{l}0.147 \\
0.094\end{array}$ & 0.059 & -0.088 \\
\hline$B$ & Assurance & 0.161 & 0.058 & -0.051 \\
\hline c & $\begin{array}{c}\text { Reliability } \\
\text { Agility } \\
\text { Assurance in Service Execution } \\
\text { Credibility } \\
\end{array}$ & $\begin{array}{l}0.341 \\
0.322 \\
0.202 \\
0.064 \\
\end{array}$ & 0.455 & 0.328 \\
\hline D & $\begin{array}{l}\text { Competence } \\
\text { Credibility }\end{array}$ & $\begin{array}{l}0.376 \\
0.304\end{array}$ & 0.212 & 0.007 \\
\hline
\end{tabular}

Source: Data from research.

The greater value of the $R^{2}$ determinant coefficient was found in Study C (0.455), which means that $45.5 \%$ of Customer Satisfaction (dependent variable) is explained by the independent variables (attributes) retained in the factor analyses. Study D explains $21.2 \%$ of Customer Satisfaction, and Studies $A$ and $B$, almost $6 \%$ each, which is a low value explained by the small sample size, as previously mentioned.

The values obtained in the adjusted $R^{2}$ were also low. Hair Jr. et al. (2010) stressed that when independent variables are added in the regression analyses, besides increasing the $\mathrm{R}^{2}$ determinant coefficient, the adjusted $\mathrm{R}^{2}$ may have its value reduced. It happened in the regression analyses performed in this research. This situation usually happens when the independent variables added show 
reduced explanation power or a low degree of freedom. The degree of freedom, when presents high values, confirms the prevision robustness concerning the respondents' sample, according to Hair Jr. et al. (2010) and Tabachnick and Fidell (2012). Again, from this information, the obtained results are justified due to the small sample size for this kind of analysis and influence the degrees of freedom.

\subsection{Comparative of studies results}

Figure 2 compares the results obtained in the factor analyses and regression analyses of each of the four studies.

Figure 2

Comparative of Analyses Results

\begin{tabular}{|c|c|c|c|}
\hline Studies & $\begin{array}{c}\text { Services } \\
\text { and Scales }\end{array}$ & Factor Analyses & Regression Analyses \\
\hline A & $\begin{array}{l}\text { Concrete } \\
\text { specimen } \\
\text { breaking / } \\
\text { adapted } \\
\text { SERVQUAL }\end{array}$ & $\begin{array}{l}\text { - All dimensions presented negative gaps } \\
\text { - Empathy and reliability presented the } \\
\text { greater negative gaps, followed by } \\
\text { assurance } \\
\text { - The attribute "Provide results in a clear } \\
\text { and easy way" showed the highest gap } \\
(-3.414)\end{array}$ & $\begin{array}{l}\text { - Reliability and assurance were the most } \\
\text { important dimensions } \\
\text { - These dimensions are related to attributes } \\
\text { like providing results in a clear and easy } \\
\text { way, staff willing to help the customers, } \\
\text { comply with the promised deadline, staff } \\
\text { knowledge, and safety }\end{array}$ \\
\hline B & $\begin{array}{l}\text { Ceramic } \\
\text { brick- } \\
\text { breaking / } \\
\text { adapted } \\
\text { SERVQUAL }\end{array}$ & $\begin{array}{l}\text { - All dimensions presented negative gaps } \\
\text { - The attributes were grouped into three } \\
\text { dimensions: reliability, responsiveness, and } \\
\text { assurance } \\
\text { - Assurance retained just one attribute, } \\
\text { what is a limitation of the study }\end{array}$ & $\begin{array}{l}\text { - Assurance was the only dimension with a } \\
\text { positive result in the regression analyses, } \\
\text { although it contains only one attribute and, } \\
\text { therefore, has no predictive character. }\end{array}$ \\
\hline C & $\begin{array}{l}\text { Concrete } \\
\text { specimen } \\
\text { breaking / } \\
\text { Lazzari }\end{array}$ & $\begin{array}{l}\text { - The study resulted in seven dimensions, all } \\
\text { of which presented good Cronbach's Alpha } \\
\text { explanation power }\end{array}$ & $\begin{array}{l}\text { - Reliability, agility, assurance in service } \\
\text { execution, and credibility were the most } \\
\text { important dimensions } \\
\text { - These dimensions are related to attributes } \\
\text { like the agility in the attendance (telephone } \\
\text { and e-mail), doubts clarification and } \\
\text { explanations related to the assays and } \\
\text { results, technical solutions, business hours, } \\
\text { and staff commitment }\end{array}$ \\
\hline $\mathrm{D}$ & $\begin{array}{l}\text { Ceramic } \\
\text { brick } \\
\text { breaking / } \\
\text { Lazzari }\end{array}$ & $\begin{array}{l}\text { - The study resulted in six dimensions, all of } \\
\text { which presented good Cronbach's Alpha } \\
\text { and explanation power }\end{array}$ & $\begin{array}{l}\text { - Competence and credibility were the most } \\
\text { important dimension } \\
\text { - These dimensions are related to attributes } \\
\text { like the sample collection service, assay } \\
\text { performing according to established norms, } \\
\text { confidentiality, and results reliability }\end{array}$ \\
\hline
\end{tabular}

Source: Data from research.

In study A, the most important dimensions found in the regression analyses were Assurance and Reliability. The dimensions concern attributes like providing results in a clear and easy way, staff willing 
to help the customers, and complying with the promised deadline, staff knowledge, and safety. In the factor analyses, the attribute with the highest negative gap was "Provide results in a clear and easy way." Currently, the results are only posted online on the university website in a report format. However, the customer is not communicated for further explanations. The attribute "Communicate the customer when the service is performed" presented the second-highest gap. That is, customers are not satisfied with the way this step is being performed. In general, all dimensions presented a negative gap, indicating that the service cycle must be reevaluated and improved.

In study B, dimension Assurance is the most important in the regression analyses, which concerns the attribute "Staff who know how to identify the customers' needs." In the factor analyses, all attributes presented negative gaps. Among them, it is stressed "Staff makes customers feel safe in negotiations," "Offer individualized care to customers," and "Staff who give personalized attention to customers." One result corroborates the other, reinforcing that individualized and personalized care are essential in customers' perceptions.

In study C, the dimensions that stood out were Reliability, Agility, Assurance in service execution, and Credibility, although in the factor analyses, "assurance in service execution" presented the lowest Cronbach's Alpha. The dimensions are related to attributes like agility in attendance (telephone and e-mail), doubts clarification and explanations related to the assays and results, technical solutions, business hours, and staff commitment.

Finally, in Study D, in customers' perceptions, Competence and Credibility are the most important dimensions, which concern attributes like the sample collection service, assay performing according to established norms, confidentiality, and reliability of results. The efficiency in the results availability can be improved by sending an e-mail informing that the reports are available since some customers take months to visualize the results.

\section{Final considerations}

The research results indicated that the variables have explanatory power. However, they have not presented statistical significance. Still, the results are coherent with the ones obtained in the factor analyses previously performed and indicate improvements to be performed by the laboratory to increase customer satisfaction.

Although applying different scales and concerning different services, some similarities can be pointed in the four analyzed studies. Attributes concerning information about the assay results, communication about the services, personalized care, and staff commitment could be identified in all studies as the most important ones.

In summary, the research results sign for the improvement of the services provided by the laboratory. Specifically, what concerns the concrete specimen breaking and ceramic brick-breaking 
services adding value to the customer service and, consequently, empowering customer satisfaction. A revision of the service cycle is indicated, where simple steps could solve some issues and increase customers' satisfaction. For example, customers could be notified by e-mail or telephone when the assay results are available, and, this way, they could also clear doubts about the results.

The results also indicate that customers prioritize personalized care and attendance. They want to feel that they are essential for the service provider. Again, this personalized care could be solved by calling or e-mailing the customers or providing an online platform where customers could get in touch. Also, this shows that the staff is committed to the customers and their needs.

In addition, a significant contribution regarding the present study was adapting the most assertive way that managers could proceed with a quality evaluation, being them about their attributes, or their dimensions, considering the analyzed context (civil construction technology laboratory) and its particularities. Albrecht and Brandford (1990) affirmed that customers are temporary patrimony. If they are not treated with zeal, with competitiveness increase, they look for another supplier that answers their needs more efficiently. Besides the personalized attendance, the customer must be informed about the importance and the information containing the results and how they can aggregate value to their final product. Preventing incomplete information to perform the assays, the necessary information that the laboratory needs to perform its job properly could be standardized in a report format collected from all customers.

After performing the proper adequacies, new research must be performed to verify whether there were alterations in customers' perceptions. This kind of improvement is crucial for the laboratory since it provides a particular service and holds the university's image. In addition, future researches are suggested to investigate the satisfaction of the customers with concrete specimen breaking and ceramic brick-breaking services as an antecedent of repurchase intention, retention, and/or customer loyalty with the laboratory.

Besides that, we point to the need for studies that replicate quality attributes and dimension evaluation resulting from the present study, whether in the analyzed context, with a new cross-section study or a longitudinal follow-up, either in the Brazilian context or in other countries (the USA, for example). Real estate buyers may have quite different expectations and perceptions, considering the constructive patterns, the desired housing standards, and the legislation that governs the civil construction sector.

As a study limitation, the small sample size can be pointed, which is small due to the small population. Such fact could have influenced the results by also influencing the methodology procedures in the regression analyses. Future research could also incorporate other kinds of services performed by the laboratory, identify similarities in results, and embrace the most significant part of the customers in the same research. Finally, through the suggested improvements and service quality management, the 
technology laboratory tends to optimize and improve its relationship with customers by improving the service quality and their customers' satisfaction.

\section{References}

Alan, W., Zeithaml, V. A., Bitner, M. J., \& Gremler, D. D. (2012). Services marketing: integrating customer focus across the firm. New York: McGraw-Hill.

Albrecht, K., \& Bradford, L. J. (1990). The service advantage: how to identify and fulfill customer needs. Irwin Professional Publishing.

Cheng, J., Proverbs, D. G., \& Oduoza, C. F. (2006). The satisfaction levels of UK construction clients based on the performance of consultants: results of a case study. Engineering, Construction and Architectural Management, 13(6), 567-583. https://doi.org/10.1108/09699980610712373

Da Silva, M. B. C., Pagnussat, D. T., Milan, G. S., Bebber, S., Rauber, M. R., \& Graciola, A. P. (2017). Service quality evaluation in the context of a technology laboratory. Environmental Quality Management, 27(2), 63-70. https://doi.org/10.1002/tqem.21529

Da Silva, M. B. C., Pagnussat, D. T., Bebber, S., Milan, G. S., \& Dal Soglio, A. (2018). A study about the quality of the services provided by a technology laboratory. Exacta, 16(2), 107-117. https://doi.org/10.5585/ExactaEP.v16n2.7591

Fink, A. (2012). How to conduct surveys: a step-by-step guide. $5^{\text {th }}$ edition. Thousand Oaks: Sage Publications.

Fitzsimmons, J. A., Fitzsimmons, M. J., \& Bordoloi, S. (2008). Service management: operations, strategy, and information technology. New York: McGraw-Hill.

Forsythe, P. (2012). Profiling customer perceived service quality expectations in made-to-order housing construction in Australia. Engineering, Construction and Architectural Management, 19(6), 587-609. https://doi.org/10.1108/09699981211277522

Fowler Jr., F. J. (2009). Survey research methods. $4^{\text {th }}$ edition. Thousand Oaks: Sage.

Freund, J. E. (2004). Modern elementary statistics. $12^{\text {nd }}$ edition New Jersey: Pearson / Prentice Hall.

Ganguli, S., \& Roy, S. K. (2011). Generic technology-based service quality dimensions in banking: Impact on customer satisfaction and loyalty. International Journal of Bank Marketing, 29(2), 168-189. https://doi.org/10.1108/02652321111107648

George, A., \& Kumar, G. G. (2014). Impact of service quality dimensions in internet banking on customer satisfaction. Decision, 41(1), 73-85. https://doi.org/10.1007/s40622-014-0028-2

Gorsuch, R. L. (2015). Factor analysis. Classic Editions. New York: Routledge.

Gounaris, S. (2005). Measuring service quality in B2B services: an evaluation of the SERVQUAL scale vis-à-vis the INDSERV scale. Journal of Services Marketing, 19(6), 421-435.

https://doi.org/10.1108/08876040510620193 
Gremler, D. D. \& Gwinner, K. P. (2000). Customer-employee rapport in service relationships. Journal of Service Research, 3(1), 82-104. https://doi.org/10.1177/109467050031006

Grönroos, C. (2007). Service management and marketing: customer management in service competition. $3^{\text {rd }}$ edition. London: John \& Wiley Sons.

Gummesson, E. (2002). Relationship marketing in the new economy. Journal of Relationship Marketing, 1(1), 37-57. https://doi.org/10.1300/J366v01n01_04

Gupta, K. K., \& Bansal, I. (2012). Development of an instrument to measure internet banking service quality in India. Researchers World, 3(2 / Part 2), 11.

Hair Jr., J. F.; Anderson, R. E., Tatham, R. L., \& Black, W. C. (2010). Multivariate data analysis: a global perspective. New York: Pearson.

IBGE - Instituto Brasileiro de Geografia e Estatística. PAS 2015: setor de serviços gera receita de $R \$ 1,4$ trilhão. 2017. Available at: https://agenciadenoticias.ibge.gov.br/agencia-noticias/2013agencia-de-noticias/releases/16889-pas-2015-setor-de-servicos-gera-receita-de-r-1-4trilhao.html. Access in: May 21, 2018.

Johne, A., \& Storey, C. (1998). New service development: a review of the literature and annotated bibliography. European Journal of Marketing, 32(3/4), 184-251. https://doi.org/10.1108/03090569810204526

Johnson, R. A., \& Wickern, D. W. (2007). Applied multivariate statistical analysis. $6^{\text {th }}$ edition. Upper Saddle River: Pearson / Prentice Hall.

Junnonen, J. M., Sorlvala, V. M. \& Kärnä, S. (2009). Classifying and clustering construction projects by customer satisfaction. Facilities, 27(9/10), 387-98. https://doi.org/10.1108/02632770910969621

Juran, J. M. \& De Feo, J. (2010). Juran's quality handbook: the complete guide to performance excellence. $6^{\text {th }}$ edition. New York: McGraw-Hill.

Kaatz, C. (2020). Retail in my pocket-replicating and extending the construct of service quality into the mobile commerce context. Journal of Retailing and Consumer Services, 53.

https://doi.org/10.1016/j.jretconser.2019.101983

Lazzari, F. (2009). Dimensões da qualidade na prestação de serviços: um estudo ambientado nos laboratórios da Universidade de Caxias do Sul. Dissertação (Mestrado em Administração). Caxias do Sul: Universidade de Caxias do Sul.

Lee, H., Lee, Y. \& Yoo, D. (2000). The determinants of perceived service quality and its relationship with satisfaction. Journal of Services Marketing, 14(3), 217-31. https://doi.org/10.1108/08876040010327220

Liu, P. \& Tse, E. C. Y. (2018). Exploring factors on customers' restaurant choice: an analysis of restaurant attributes. British Food Journal, 120(10), 2289-2303. https://doi.org/10.1108/BFJ10-2017-0561

Malhotra, N. K., Birks, D., \& Wills, P. (2012). Marketing research: applied approach. $4^{\text {th }}$ edition. New York: Pearson. 
Marimon, F., Llach, J., Alonso-Almeida, M., \& Mas-Machuca, M. (2019). CC-Qual: A holistic scale to assess customer perceptions of service quality of collaborative consumption services. International Journal of Information Management, 49, 130-141. https://doi.org/10.1016/j.ijinfomgt.2019.03.009

Meyers, L. S., Gamst, G. C., \& Guarino, A. J. (2013). Applied multivariate research: design and interpretation. $2^{\text {nd }}$ edition. Thousand Oaks: Sage Publications.

Milan, G. S., Da Silva, M. B. C., Bebber, S., \& De Toni, D. (2014). Multifamily buildings construction's service quality in Brazil. Australian Journal of Basic \& Applied Science, 8(15), 42-52.

Mulaik, S. A. (2010). Foundations of factor analysis. $2^{\text {nd }}$ edition. Boca Raton: Taylor \& Francis Group.

Oh, H., \& Kim, K. (2017). Customer satisfaction, service quality, and customer value: years 20002015. International Journal of Contemporary Hospitality Management, 29(1), 2-29. https://doi.org/10.1108/IJCHM-10-2015-0594

Oliver, R. L. (2010). Satisfaction: a behavioral perspective on the consumer. $2^{\text {nd }}$ edition. New York: M. E. Sharpe.

Parasuraman, A., Zeithaml, V. A., \& Berry, L. L. (1988). SERVQUAL: a multi item scale for measuring consumer perception of service quality. Journal of Retailing, 64(12), 12-40.

Punel, A., Hassan, L. A. H., \& Ermagun, A. (2019). Variations in airline passenger expectation of service quality across the globe. Tourism Management, 75, 491-508. https://doi.org/10.1016/j.tourman.2019.06.004

Quan, S. (2010). The relationships among e-service quality, system quality, information quality and customer loyalty: an empirical study of internet banking in China. Global Journal of Management and Business Research, 10(7), 27-34.

Tabachnick, B. G., \& Fidell, L. S. (2012). Using multivariate statistics. $6^{\text {th }}$ edition. Boston: Pearson.

Valenzuela, F., Estocalenko, J., Rojas, J., \& Raymundo, C. (2019, August). Lean Service Quality Model to Improve the Performance of Service in Automotive Dealer. In International Conference on Human Interaction and Emerging Technologies (pp. 917-923). Springer, Cham. 